sent certain waves or particles into the earth's atmosphere. Previously there has been no way of identifying the magnetic disturbances associated with such eruptions. As the radio effects are easily identified, it is hoped to get a closer insight into the connexion between them and solar disturbances. In a later report by Prof. H. G. Gale of Mount Wilson Observatory, it is stated that on the morning of October 24 a group of dark granular flocculi was observed on the sun's disk. This group was observed frequently during the day, and at its maximum it was the largest object on the sun's surface as observed by the hydrogen spectroheliograph. The increased solar activity paralleled the strange radio fade-out. Technical details are given in the November 15 issue of the Physical Review.

\section{Science and Vegetable Production}

Mr. F. A. Secretr lectured before the Royal Society of Arts on November 27, the subject of the discourse being "Modern Methods of Vegetable Production and Marketing". Mr. Secrett, as the owner of Holly Lodge Farm, Walton-on-Thames, is well qualified to speak on this topic (see NATURE, May 25, p. 866). Mr. Secrett's outlook combines the enthusiasm of the amateur with business acumen and scientific discrimination. One of the problems of intensive culture is to obtain sufficient humus for the soil. Sewage waste and town refuse may possibly fill the need, but Mr. Secrett insisted that fresh or green manure has a denitrifying effect on the soil. The technique of irrigation by overhead sprays, and of heating the soil by hot water pipes laid in troughs of water below the soil, were described in detail, for Mr. Secrett is an authoritative exponent and pioneer in the application of these practices. Particular attention was given to methods of aerating the irrigation water, and of incorporating soluble fertilisers. The section on marketing dealt with the use of non-returnable packages, the reorganisation of commission sales, and the revision of railway rates. Much criticism of the work of marketing boards was given, and Mr. Secrett showed, by reasoned argument and without caustic remark, that the unvaried edict of bureaucratic control is often opposed to the best interests of a dynamic and changeable industry such as vegetable growing.

\section{Mount Everest Expedition}

IN preparation for the new Mount Everest expedition of 1936, a reconnaissance party was at work last year. At the Royal Geographical Society on December 2, Mr. E. E. Shipton gave an account of this expedition. The main objects were to investigate snow conditions at high altitudes and decide on the best season for the attempt on the summit, to examine the possibility of alternative routes either by the north-west ridge from the head of the Central Rongbuk glacier or by the unknown Western Cwm, and to test equipment. An exploration of the western approaches to Mount Everest revealed no possible way of approach to the summit. Moreover, it was found that the ice slopes of the North Col were in a very dangerous condition during the whole of the monsoon, and always liable to be swept by avalanches the occurrence of which it was impossible to foretell. The expedition scaled numerous hitherto unclimbed peaks in the district in the course of its work.

\section{Housing and Overcrowding}

THE Ministry of Health has recently issued several circulars dealing with the subjects of housing and overcrowding, all published by H.M. Stationery Office. "Housing" (2d. net) summarises the principal provisions of the Housing and Public Health Acts in relation to maintenance of dwellings in a reasonably fit condition. "Housing, England" (Statutory Rules and Orders 1935 No. 1115 . 1d. net) relates to the appointment of a committee, to be called the Central Housing Advisory Committee, for the purpose of advising the Minister on questions relating to overcrowding. "Circular 1507" deals with Section 1, Housing Act, 1935, and fixes dates for (1) the completion of inspection-April 1, 1936, (2) submission of report-June I, 1936, and (3) submission of proposals-August 1, 1936. "Statutory Rules and Orders 1935 No. 1086" (3d. net) makes regulations applying to polls of local government electors in connexion with the promotion of bills by councils other than councils of metropolitan boroughs. The Central Housing Advisory Committee appointed by Sir Kingsley Wood includes among other prominent members the names of Lord Balfour of Burleigh, the Earl of Crawford and Balcarres and the Earl of Dudley, the Bishop of Winchester, Miss Megan Lloyd George, Sir Francis Fremantle, Dr. Greenwood Wilson and Mr. Silkin.

\section{A Long Barrow in East Anglia}

IT has been supposed that no long barrows exist in Norfolk and Suffolk, and various theories have been put forward to account for the absence of the long-barrow culture in these counties. Some have supposed that it never existed in these areas, while others have thought that the non-existence of the burial mounds is to be accounted for by their removal through ploughing or other agricultural operations. It now seems that the latter is the more likely explanation as, recently, Mr. J. E. Sainty, of The Hedges, West Runton, near Cromer, and his friend Mr. A. Q. Watson, of Holt, have discovered, in west Norfolk, what has every appearance of being a long barrow, surrounded by a ditch. This is a noteworthy find and the discoverers hope to be able to excavate the site in the near future.

\section{Science in the Public Press}

WE are glad to direct attention to a series of eight articles on scientific problems of particular human interest now being contributed to the Evening Standard by competent authorities on the subjects with which they deal. The first article, by Prof. H. Levy, in the issue of December 9, presents a philosophic picture of the universe. Succeeding articles in the series are "What is Death?", Prof. J. B. S. 
Haldane; "Is There an After-life ?", the Bishop of Birmingham ; "Can We Create Life ?", Prof. F. G. Donnan; "Is There Life on the Planets ?", Dr. H. Spencer Jones ; "Why Do I Dream ?", Prof. Cyril Burt; "Can We Harness the Atom ?", Prof. E. N. da C. Andrade; and "What Is My Conscience?", Prof. J. C. Flügel.

\section{New Research Laboratory of the L.M.S.}

ON December 10, Lord Rutherford opened the new L.M.S. Railway research laboratory at Derby in the presence of many well-known scientific workers and industrialists. Before the special train left St. Pancras, Pat Rutherford, grandson of Lord Rutherford, had the honour of naming the new Crewe-built engine of the special train. Sir Josiah Stamp first introduced him to the leading guests and then lifted him on to the running-plate of the engine. A purple cloth covered the name-plate. Pat pulled the cord to unveil the plate and called out, "I name this engine 'Lord Rutherford of Nelson'". We propose to print an account of the speeches made at the opening of the new laboratory at Derby in our next issue.

\section{The 200-inch Disk for the Mount Wilson Observatory}

According to the New York correspondent of The Times, the second two hundred inch pyrex glass disk which has been made at the Corning Works for the California Institute of Technology has been accepted as satisfactory by the scientific representatives of that institution. The disk has been annealing for twelve months, and it is expected that the process of grinding and figuring, which will take place at Pasadena, Cal., will occupy five years. There are said to be some flaws on the surface of the disk : these were caused through the floods of this summer, which shut off the heating apparatus for forty-eight hours, but they will be removed during the grinding process. Astronomers and others on the east of the Atlantic who have followed the not uneventful history of the manufacture of the mirror for the two hundred inch telescope with great interest, will be glad to hear that the present disk is satisfactory, and will wish their American colleagues a little luck, of which perhaps they have not yet had their share, in their delicate and long-continued operations on this large disk.

\section{Announcements}

THE honorary membership of the Royal Asiatic Society has been conferred upon Prof. Wilhelm Geiger, of the University of Munich, in recognition of his eminent services to Indian and Iranian philology.

THE following appointments have recently been made by the Secretary of State for the Colonies: Mr. J. C. Cater, to be assistant conservator of forests, Trinidad ; Mr. H. E. C. Lewys-Lloyd, stock inspector, Tanganyika, to be assistant live stock officer, Uganda.

Dr. Wilsur A. SAwyer has been appointed director of the Division of International Health of the Rockefeller Institute, New York.
ThE fourth International Congress of Cytology will be held in Copenhagen in 1936. The exact date has not yet been fixed, but the Congress will probably take place in August. Further information can be obtained from the General Secretary, Nassaustrasse 17, Berlin-Wilmersdorf.

THE Iron and Steel Institute is offering a number of grants from the research fund founded by $\mathrm{Mr}$. Andrew Carnegie in aid of metallurgical research. Candidates for grants must be less than thirty-five years of age. Applications should be made before January 10 to the Secretary, Iron and Steel Institute, 28 Victoria Street, London, S.W.1.

The first International Congress of Criminal Anthropology and Psychiatry will be held in Rome next April, when the following subjects will be discussed : etiology, diagnosis and prognosis of criminality in minors; prophylaxis of crime in relation to penal laws; fundamental conception of criminal biology; and prophylaxis of crime and criminal anthropology. Visits will be paid to the various Italian institutions for the prevention of criminality and re-education of delinquents in Rome, Naples, Orvieto and elsewhere. Further information can be obtained from the general secretary, Prof. B. di Tullio, via Giulia 52, Rome.

A PRACTICAL brochure entitled "Instructions for Collectors: No. 4-Insects", published by the British Museum (Natural History), has recently appeared in its eighth edition. It gives instructions, intended chiefly for persons travelling abroad, as regards the best methods for collecting insects and the essential apparatus. It is obtainable from the Museum or through booksellers, price $3 d$. (postage $1 d$ ).

Applications are invited for the following appointments, on or before the dates mentioned :

A part-time lecturer in practical mathematics in East Ham Technical College-The Secretary for Education. Town Hall, East Ham, E.6 (Dec. 17).

A scientific officer at the Building Research Station, Garston-The Establishment Officer, Department of Scientific and Industrial Research, 16 Old Queen Street, Westminster, S.W.1 (Dec. 19).

An assistant instructor in dairying to the Wilts County Council-The Clerk of the Council, County Offices, Trowbridge (Dec. 19).

Pharmacist-inspectors to the Pharmaceutical Society of Great Britain-The Secretary of the Society, 17 Bloomsbury Square, W.C.1 (Jan. 1).

A professor of mathematical physics in the Indian Institute of Science, Bangalore-The Director (Jan. 15).

A professor of physiology in the University of Queensland-The Secretary, Universities Bureau, 88A Gower Street, W.C.l (Jan. 25).

An assistant lecturer in mathematical physics in University College, Hull-The Registrar.

An assistant lecturer in chemistry in the Huddersfield Technical College--The Director of Education, Education Offices, Peel Street, Huddersfield. 